\title{
Synthesis, Characteristics and Physico-chemical Study of Some Dichloro Pyrazoles
}

\author{
Suchita Nimbalkar \\ St. Vincent Pallotti College of Engineering \& Technology \\ Nagpur (Maharashtra), India \\ Tel: 94-23-410-141_E-mail: suchitadn@yahoo.co.in
}

Received: July 29, 2011

Accepted: September 22, $2011 \quad$ Published: April 1, 2012

doi:10.5539/ijc.v4n2p108

URL: http://dx.doi.org/10.5539/ijc.v4n2p108

\begin{abstract}
Some new 3,5-Diaryl-1-substituted pyrazoles have been synthesized by the action of isonicotinic acid and thio-semicarbazide on 3-iodo flavanones in pyridine medium. 3-iodo flavanones obtained from 2-hydroxy-3,5-dichloro chalcones and ICl in acetic acid. Structure of these compounds has been established by chemical and spectral analysis (NMR \& IR). Purity of these heterocycles was checked by TLC. The interaction of $\mathrm{Cu}(\mathrm{II}), \mathrm{Co}(\mathrm{II})$ with 1-carboxamido-3-(2-hydroxy-3,5-dichloro pheyl)-5-(4-methoxy phenyl) pyrazole $\left(\mathrm{L}_{1}\right)$, 1-thiocarbaxomedo-3(2-hydroxy-3,5-dichloro pheyl)-5-(4-methoxyophenyl) pyrazole $\left(\mathrm{L}_{2}\right)$ have been carried out by employing Bjerrum -Calvin $\mathrm{pH}$ metric titration technique, at $27 \mathrm{C}$ in $70 \%$ dioxane-water medium. The data obtained can be used for the determination of proton ligand formation numbers $(\eta)$. From the formation curve, the proton-ligand stability constant $\mathrm{pK}$ values have been evaluated using half integral method. The metal ligand formation numbers $(\eta)$ are estimated by using Irving Rossotti's expression.
\end{abstract}

Metal-Ligand stability constants for 1:1 complex \& 1:2 complex have been calculated which are designated by letters $\log \mathrm{K}_{1} \& \log \mathrm{K}_{2}$ respectively.

Keywords: 1-(2-hydroxy-3,5-dichlorophenyl)-3-aryl-prop-2-ene-1-ones, 3-iodo flavanones, 3,5-Diaryl-1-substituted pyrazoles, Proton-Ligand formation numbers, Metal-Ligand stability constants<smiles>O=C(Cl)c1cc(Cl)cc(Cl)c1O</smiles><smiles>[R2]Cn1nc(-c2cc(Cl)cc(Cl)c2O)cc1-c1ccc([R])c([R])c1</smiles> 


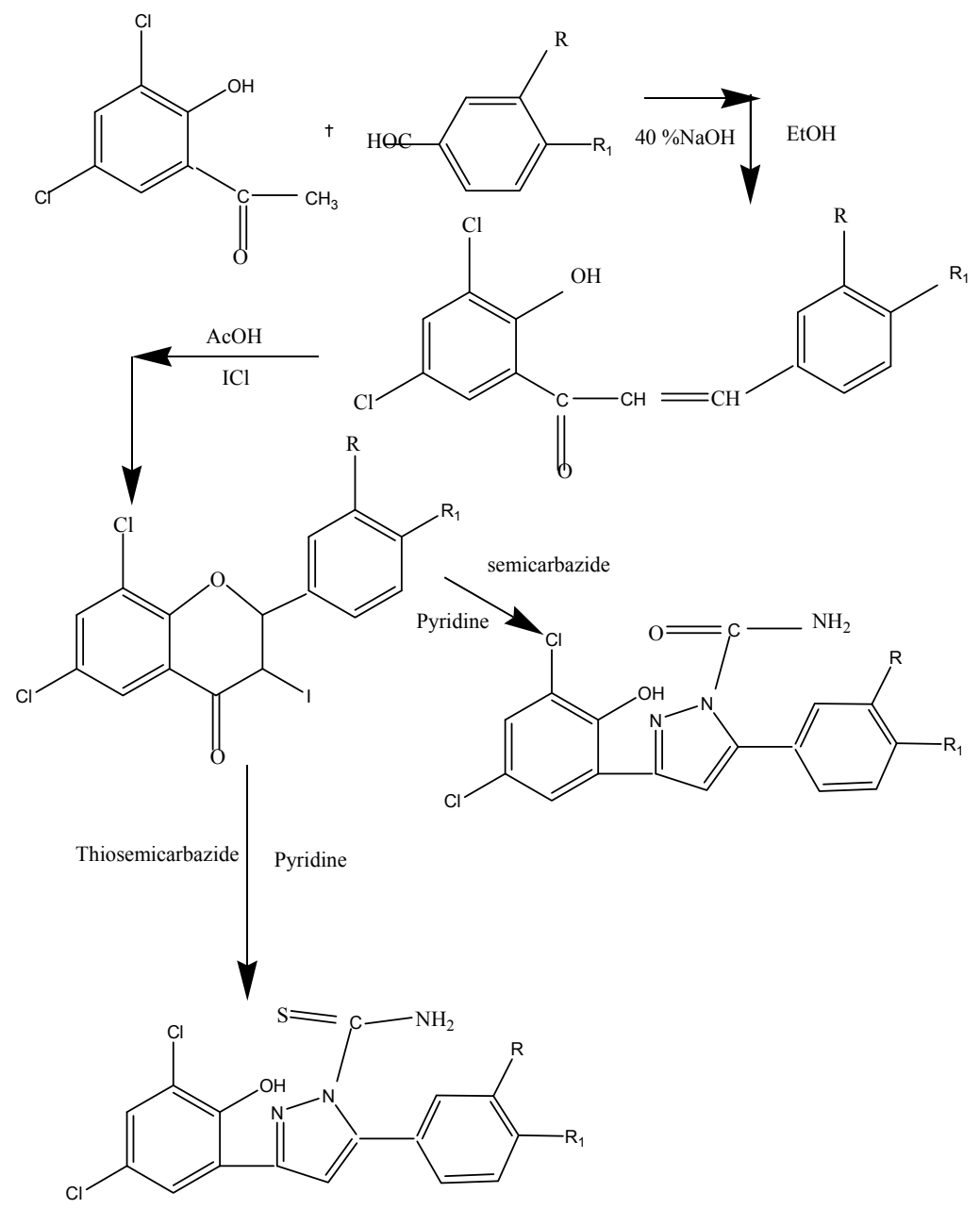

\section{Introduction}

The literature survey reveals the importance of chalcones and flavanones as a valuable starting materials for synthesis of hetero cycles like pyrazolines, pyrazoles \& isoxaxolines etc. Formation of pyrazoles has been reported by many scientists. Pyrazoles are found widely useful in drugs $\&$ dyes. These compounds also show physiological activities (E. Herman \& J. Gablis, 1961; I. I. Grandbery et al., 1962; M. V. Kadu \& V. S. Jamode, 1998). Trifluoromethyl-1-aryl derivatives of pyrazoles are used as analgesic, antipyretic and anti inflammatory agents (R. G. Micetich \& R. B. Rastigl, 1983), 1-phenyl derivatives are effective antidiabetics (P. L. Anderson \& N. A. Paolella, 1982). Acyl amine and chloro pyrazoles have been found to be effective herbicide (El Saied A. Aly et al., 2004) Phenyl pyrazoles act as insecticides (Thakre V. G., 1989), antimicrobial agents (Moged A. Berghot \& Evelin B. Moawad, 2003), hypolipidermic agents (Seki, K. et al., 1984) etc. Substituted pyrazoles are found to be excellent anti fungal agent (Sakamepo Hidekazu et al., 1988), Number of pyrazole derivatives have been synthesized and found to posses biological activity (Rajeev Jain \& Seema Gupta, 1996).

It has been suggested that biological evaluation of new bio active molecules containing pyrazol nucleus is important for the creation of promising new analgesic agents (J. Milano et al., 2008; Z. Tabarelli et al., 2004; M. C. Godoy et al., 2004).

Some new heterometalic Ge(IV) and $\mathrm{Co}(\mathrm{II}), \mathrm{Ni}(\mathrm{II})$ and $\mathrm{Cu}(\mathrm{II})$ complexes based on ethylene diamine tetra acetic acid (EDTA) were synthesized (E. E. Martsinko et al., 2005).

Some physicochemical constants of some compounds were analyzed by spectral characteristics (Ya. A. Shuster et al., 1974).

Some substituted benzyl groups resulted in marked improvements in potency, ligand efficiency and Ligand-lipophilicity efficiency (Charles E. Mowbray et al., 2009).

The route for the synthesis of some pyrazole derivatives from substituted 3-iodo flavanones are obtained according to the literature procedure (M. G. Joshi, 1983). The literature survey clearly indicate these newly 
1-substituted-3,5-diaryl pyrazoles are not get synthesized.

In view of analytical application of pyrazoles dissociable hydroxy (-OH) group is necessary to know the physico-chemical properties such as proton-ligand \& metal-ligand stability constant. Sawalakhe P. D., Narwade M. L. (1994), have investigated the metal-ligand stability constant of $\mathrm{Fe}(\mathrm{II}), \mathrm{Cr}(\mathrm{III}), \mathrm{Al}(\mathrm{III})$ metal ion complexes with some substituted pyrazoles \& pyrazolienes. Narwade et al. (1994) studied formation and stability constants of $\mathrm{Th}(\mathrm{IV})$ complexes with some substituted pyrazolines. The complexes of some bivalent metal ions such as $\mathrm{Co}(\mathrm{II})$, $\mathrm{Ni}(\mathrm{II}), \mathrm{Zn}(\mathrm{II}), \mathrm{Cd}(\mathrm{II})$ and $\mathrm{Hg}$ (II) with 4-amino-3-thio-6-methyl-2,3,4,5-tetrahydro-1,2,4-triazine have been investigated by Singh et al. (1988). Similarly the derivative of triazines formed complexes with Ni(II), Pd(II), and $\mathrm{Pt}(\mathrm{II})$ metal ion have been reported (Vogel A. I., 1977).

But $\mathrm{Cu}(\mathrm{II}), \mathrm{Ni}(\mathrm{II})$ with newly synthesized substituted pyrazoles in the laboratory have not been studied for complex formation. It was therefore thought of interest to confirm the dissociation of -OH group and study the stability constant of these substituted pyrazoles with $\mathrm{Cu}(\mathrm{II})$ and $\mathrm{Ni}(\mathrm{II})$ metal ions under the suitable condition $\mathrm{pH}$-metrically at $0.1 \mathrm{M}$ ionic strength.

\section{Experimental}

Melting points are uncorrected. IR spectra in KOH were recorded on PE-577/ PE-781 IR spectrophotometry. NMR in DMSO were in Brucker spectrophotometer (EM 390).

\subsection{Preparation of 2-hydroxy-3-5-dichloro Chalcones (1a)}

To the boiling solution of 2 hydroxy-3,5-dichloro acetophenone $(0.01 \mathrm{Mole})$ in ethanol $(20 \mathrm{ml})$, aromatic aldehyde $(0.01 \mathrm{~mole})$ was added. Then $40 \%$ solution of $\mathrm{NaOH}$ ( 3 mole) added slowly. The mixture was stirred mechanically at room temp for one hour till it was solidified. It was decomposed after 6 to 8 hours with ice cold 1:1 HCl. Yellow colored solid obtained was filtered. Wash with sufficient water. The product obtained was crystallized from ethanol acetic acid mixture to get yellow crystals of chalcone physical data of 2-hydroxy-3-5-dichloro chalcones (1a) were recorded in table 1 .

\subsection{Preparation of 3-iodo Flavanones (2a)}

Chalcone was suspended in ethanol and then treated with ICl in glacial acetic acid. The reaction mixture was brought to boiling. The solid that separated on cooling that filtered after two hours and crystallized from acetic acid and ethanol mixture. Physical data of 3-iodo flavanones (2a) is recorded in table 2.

\subsection{Preparation of 3-5 diaryl Pyrazoles (3a-3b)}

A Mixture of 3-iodoflavanone (0.01 mole), nucleophile $(0.02$ mole $)$ such as Isonicotinic acid hydrazide, semicarbazide and thiosemicarbazide in pyridine $(40 \mathrm{ml})$ was refluxed for 5 hours. The reaction mixture was diluted by 1:1 $\mathrm{HCl}$. The product obtained was crystallized from ethanol-acetic acid mixture to get pale yellow product. Physical data of series (3a-3b) recorded in table 3.

\section{Experimental for Physico-chemical Studies}

$\mathrm{pH}$ metric titration are carried out by using following chemicals

1) Distilled water: Carbon dioxide free distilled water is used. This water was redistilled by passing over alkaline $\mathrm{KMnO}_{4}$ and having $\mathrm{pH} 6.94$.

2) Sodium hydroxide solution: Solution of $\mathrm{NaOH}$ free from carbonate was prepared (Vogel A. I., 1977). Solution was standardized having $0.10 \mathrm{M}$ concentration.

3) Potassium nitrate: Desire amount of $\mathrm{KNO}_{3}$ was dissolved in double distilled water to prepared $1.0 \mathrm{M}$ concentration solution.

4) Nitric acid: $\mathrm{HNO}_{3}$ was diluted with double distilled water to prepared $0.01 \mathrm{M}$ solution and it then standardized with $\mathrm{NaOH}$ Solution.

5) Metal Solutions: A.R. Grade Copper Nitrate and Nickel nitrate salts are used for preparing metal ion solution and their concentration were estimated by slandered procedure (Vogel A. I., 1977).

6) Ligand Solution: $0.01 \mathrm{M}$ ligands synthesized in our laboratory were prepared by dissolving appropriate quantity in dioxane (AR). The purity of compounds was checked by melting points, I.R. and N.M.R. Spectral data.

\subsection{Systronics Model}

$\mathrm{pH}$ meter (accessory +0.05 unit) along with standard calomel electrode and glass electrode calibrated with buffer solution of $\mathrm{pH} 4.0,7.0$ and 9.2 at $27{ }^{\circ} \mathrm{C}$ was used for the $\mathrm{pH}$ measurements. The titrations were carried out in 100 $\mathrm{ml}$ Pyrex glass beaker and temperature is maintained at $27^{\circ} \mathrm{C}$. Nitrogen gas was slowly bubbled to remove oxygen 
and carbon dioxide. The $\mathrm{pH}-$ meter readings were taken only after the gas bubbling system were considered.

Set I-Free acid titration.

A solution containing nitric acid and potassium nitrate $\left(1.0 \times 10^{-2} \mathrm{M}\right)$ in $70 \%$ dioxane - water mixture.

Set II -Free acid ligand titration.

A solution containing nitric acid, potassium nitrate and ligand $\left(20 \times 10^{-4} \mathrm{M}\right)$ in $70 \%$ dioxane - water mixture.

Set III - Free acid Metal - ligand titration.

A solution containing nitric acid, potassium nitrate, ligand and metal ion $\left(4 \times 10^{-4} \mathrm{M}\right)$ in $70 \%$ dioxane - water mixture.

From free acid titration and acid-ligand titration proton-ligand formation numbers $(\eta \mathrm{A})$ can be calculated by using formula.

$$
\eta \mathrm{A}=\mathrm{r}-\mathrm{( \textrm {E } _ { 0 } + \mathrm { N } ) \times ( \mathrm { V } _ { 2 } - \mathrm { V } _ { 1 } )}
$$

where,

$r$ - Number of dissociable protons from ligand

$\mathrm{E}_{0}$ - Concentration of $\mathrm{HNO}_{3}$

$\mathrm{N}$ - Normality of $\mathrm{NaOH}$

$\mathrm{V}_{1} \& \mathrm{~V}_{2}$ - Volume of alkali consumed by acid and ligand on same $\mathrm{pH}$

$\mathrm{V}_{0}$ - Initial Volume

$\mathrm{TL}_{0}$ - Ligand concentration

From free acid titration and Metal ligand titration, Metal-Ligand formation numbers $(\eta)$ can be calculated by using formula-

$$
\eta=\frac{\left(E_{0}+N\right) \times\left(V_{3}-V_{2}\right)}{\left(V_{0}+V_{2}\right) \times T^{0} M \times \eta A}
$$

Where, $\mathrm{T}^{0} \mathrm{M}$ - Metal concentration.

The graphs were constructed between $\mathrm{pH}$ Vs $\eta \mathrm{A}$ and $\mathrm{pH}$ Vs $\eta$. From these graphs another graphs were constructed between volumes of $\mathrm{NaOH} \mathrm{Vs} \mathrm{pH}$ of solution.

\section{Result and Discussion}

\subsection{Proton - ligand Dissociation Constant ( $p K)$}

The algebraic method has been used to determine the dissociation constants of ligands at $0.1 \mathrm{M}$ ionic strength $\mathrm{pH}-$ metrically.

The deviation of (acid + ligand) curve from acid curve started at $\mathrm{pH} 2.8$. It remains constant up to $\mathrm{pH}-9.0$ and it increased continuously up to $\mathrm{pH} 12$. This indicated dissociation of -OH group from ligand with respect to change in $\mathrm{pH}$ of solution

\subsection{Proton - ligand Formation Number}

Proton-ligand formation numbers $\eta \mathrm{A}$ were calculated from acid titration curve $(\mathrm{A})$ and $(\mathrm{A}+\mathrm{L})$ by Irving and Rassotti's expression. It was found that values of $\eta \mathrm{A}$ decreased with increasing $\mathrm{pH}$ of solution due to replacement of $\mathrm{H}^{+}$ion from -OH group.

Formation curves were constructed between the value of $\eta \mathrm{A}$ and $\mathrm{pH}$. The proton-ligand stability constants (pKL) were calculated from half integral methods i.e. $\mathrm{pH}$ at $\eta \mathrm{A}=05$ The $\mathrm{pK}$ Value of ligands are presented in table 4 .

\subsection{Metal - ligand Formation Number ( $\eta$ )}

The deviation of $(\eta+L+M)$ curves from $(A+L)$ curves started at about $\mathrm{pH}-2.5$ it indicated the complex formation. The metal-ligand formation numbers $(\eta)$ were calculated by standard equation, which shows $n$ value goes on increasing with increase in $\mathrm{pH}$ value.

The formation curves were constructed between the value of $\mathrm{pH}$ and $\eta$. The metal-ligand stability constant were 
calculated by half integral method at $\mathrm{pH}=0.5$ and 1.5 showing $1: 1$ and $1: 2$ complex formation respectively.

For 1:1 complex $\log \mathrm{K}_{1}$ is calculated from following formula

$$
\log K_{1}=\log _{K L X\left(T L_{0}-T M_{0} X_{n}\right)}^{\left[H^{+}\right]} \quad \eta=0.5
$$

And for 1:2 complex $\log \mathrm{K}_{2}$ is calculated from following formula

$$
\log K_{1}=\log \underset{K L X\left(T L_{0}-T M_{0} X_{n}\right)}{\left[H^{+}\right]} \quad \eta=1.5
$$

\section{References}

E. Herman, \& J. Gablis. (1961). Cancer Chemotherm. Rept., 14, 85.

I. I. Grandbery, S. N. Milovanova, A. N. Kast, \& I. T. Netta. (1962). Chem. Abstr., 56, 9368.

M. V. Kadu, \& V. S. Jamode. (1998). Synthesis and characterization of 3,5-Diaryl-4-Benzoyl-1-Pyridoyl Pyrazoles. Asian Journal Chem., 10(3), 480-483.

R. G. Micetich, \& R. B. Rastigl. (1983). 72087, Can CAl, 730803 CCL. CO7 D 231/12. (1982). Chem Abstr., 98, 72087.

P. L. Anderson, \& N. A. Paolella. (1982). VS 454, 399, 979 (cl. 1424- 2730) (A61 K 31/415).

El Saied A. Aly, Mohmed A. El - Borai, \& Mohamed A. Barren. (2004). A convenient synthesis of some novel pyrazole derivatives. India J. Chem. B, 43B(6), 1355.

Thakre V. G. (1989). Ph.D Thesis, Amravati University Amravati.

Moged A. Berghot, \& Evelin B. Moawad. (2003). Convergent synthesis and antibacterial activity of pyrazole and pyrazoline derivatives of diazepam. European Journal of pharmaceutical science, 20(2), 173-179. http://dx.doi.org/10.1016/S0928-0987(03)00162-3

Seki, K., Jsegewa, J., \& Fukuda. M. (1984). Chem. Abstr., 101(25), 211032 d.

Sakamepo Hidekazu, Fuziwara, Mitsutoskata, itstsew, Yamamato Susumu, \& J. Pn Kokai. (1988). Tokkyoo Knoho J., 223, 63 .

Rajeev Jain, \& Seema Gupta. (1996). J. Hetrolytic chem., 6, 71.

J. Milano, S. M. Oliveira, M. F. Rossato, P. D. Sauzem, P. Machado, P. Beck, N. Zanatta, M. A. P. Martins, C. F. Mello, M. A. Rubin, J. Ferreira, \& H. G. Bonacorso. (2008). Antinociceptive effect of novel trihalomethyl-substituted pyrazoline methyl esters in formalin and hot-plate tests in mice. Eur. J. Pharmacol., 581, 86-96. http://dx.doi.org/10.1016/j.ejphar.2007.11.042

Z. Tabarelli, M. A. Rubin, D. B. Berlese, P. D. Sauzem, T. P. Missio, M. V. Teixeira, A. P. Sinhorin, M. A.,P. Martins, N. Zanatta, H. G. Bonacorso, \& C. F. Mello, Braz. (2004). Antinociceptive effect of novel pyrazolines in mice. J. Med. Biol. Res., 37, 1531-1540. http://dx.doi.org/10.1590/S0100-879X2004001000013

M. C. Godoy, M. R. Fighera, F. R. Souza, A. E. Flores, M. A. Rubin, M. R. Oliveira, N. Zanatta, M. A. Martins, H. G. Bonacorso, \& C. F. Mello. (2004). $\alpha_{2}$-Adrenoceptors and 5-HT receptors mediate the antinociceptive effect of new pyrazolines, but not of dipyrone. Eur. J. Pharmacol., 496, 93-97. http://dx.doi.org/10.1016/j.ejphar.2004.05.045

E. E. Martsinko, I. I. Seifullina, \& V. Ya. Zub. (2005). Synthesis and Study of $\mathrm{Co}(\mathrm{II}), \mathrm{Ni}(\mathrm{II})$, and $\mathrm{Cu}(\mathrm{II})$ Ethylenediaminetetraacetatohydroxogermanates. Russian Journal of Coordination Chemistry, 31(11), 795-799. http://dx.doi.org/10.1007/s11173-005-0171-6

Ya. A. Shuster, V. A. Kozlova, \& V. I. Seraya. (1974). Spectrometric study of some N-substituted 3(5)-methylpyrazoles and their complexes with cupric chloride. Chemistry of Heterocyclic compounds, 10(12), 1455-1458. http://dx.doi.org/10.1007/BF00474328

Charles E. Mowbray, Romuald Corbau, Michael Hawes, Lyn H. Jones, James E. Mills, Manos Perros, Matthew D. Selby, Paul A. Stupple, Rob Webster, \& Anthony Wood. (2009). Pyrazole NNRTIs 3: Optimisation of physicochemical properties. Bioorganic \& Medicinal Chemistry Letters, 19(1), 5603-5606. http://dx.doi.org/10.1016/j.bmcl.2009.08.043

M. G. Joshi. (1983). Ph.D Thesis Nagpur University Nagpur.

Sawalakhe P. D., \& Narwade M. L. (1994). J. Ind. Chem. Society, 71, 49-51. 
Singh P. D., \& Mishra L. K. (1988). J. Ind. Chem. Soc., LXV(I), 21.

Santra Swapna, Chitra R., Sena, \& Sawtra P. K. (1992). Ind. J. Chem., 31(A), 3, 160.

Vogel A. I. (1977). A text book of qualitative inorganic analysis $3^{\text {rd }}$ Ed, Newyork.

Table1. Physical characterization data of 2-hydroxy-3-5-dichloro chalcones (1a)

\begin{tabular}{|c|c|c|c|c|c|}
\hline Compounds & $\mathrm{R}_{1}$ & $\mathrm{R}_{2}$ & yield \% & m.p. ${ }^{\circ} \mathrm{C}$ & Molecular formula \\
\hline $1 \mathrm{a}$ & $\mathrm{H}$ & $\mathrm{OCH}_{3}$ & 85 & $168-170$ & $\mathrm{C}_{16} \mathrm{H}_{12} \mathrm{O}_{3} \mathrm{Cl}_{2}$ \\
\hline
\end{tabular}

Spectral Interpretation of $1 \mathrm{a}$

IR (max cm$\left.{ }^{-1}\right)$ : $3068.2(\mathrm{Ar}-\mathrm{H}) ; 1599(\mathrm{C}=\mathrm{C}) ; 702,737,780,(\mathrm{C}-\mathrm{H}) ; 824$ (C-Cl); 1045 (C-O-C); $1637.3(\mathrm{C}=0)$

HNMR: OH ( $\left.\mathrm{CDCL}_{3}, \mathrm{ppm}\right) ; 3.87(\mathrm{~S}, 3 \mathrm{H}), 6.9-7(\mathrm{~m} 64), 3.53\left(\mathrm{~S}_{2} \mathrm{lH}\right)$

Table 2. Physical characterization data of 3-iodo flavanones (2a)

\begin{tabular}{|c|c|c|c|c|c|}
\hline Compounds & $\mathrm{R}_{1}$ & $\mathrm{R}_{2}$ & yield \% & m.p. ${ }^{0} \mathrm{c}$ & Molecular formula \\
\hline $2 \mathrm{a}$ & $\mathrm{H}$ & $\mathrm{OCH}_{3}$ & 70 & 180 & $\mathrm{C}_{16} \mathrm{H}_{12} \mathrm{O}_{3} \mathrm{Cl}_{2}$ \\
\hline
\end{tabular}

Spectral Interpretation of 2a

IR (max): $3075 \mathrm{~cm}^{-1}(\mathrm{Ar}-\mathrm{H}) ; 1588.4 \mathrm{~cm}^{-1}(\mathrm{c}=\mathrm{c}) ; 736,821.9 \mathrm{~cm}^{-}{ }^{1},(\mathrm{C}-\mathrm{H}) ; 635.5 \mathrm{~cm}^{-1}(\mathrm{C}-\mathrm{Cl}) ; 1068.9 \mathrm{~cm}^{-1}(\mathrm{C}-\mathrm{I})$; 1685.6, $1173.6 \mathrm{~cm}^{-1}(\mathrm{C}=0)$

1HNMR: OH ( $\left.\mathrm{CDCl}_{3}, \mathrm{ppm}\right) ; 3.8(5,3 \mathrm{H}), 4.64\left(\mathrm{~d}_{1} \mathrm{H}_{\mathrm{a}}\right) 4.84\left(\mathrm{~d}_{1} \mathrm{H}_{\mathrm{b}}\right) 6.9-7.66(\mathrm{~m} \mathrm{6h})$

Table 3. Physical characterization data 1-substituted-3,5-diaryl pyrazoles (3a-3b)

\begin{tabular}{|c|c|c|c|c|c|c|c|}
\hline Compounds & $\mathrm{R}_{1}$ & $\mathrm{R}_{2}$ & $\mathrm{R}_{3}$ & yield \% & M.P & Rf value & Molecular formula \\
\hline $3 \mathrm{a}$ & $\mathrm{H}$ & $\mathrm{OCH}_{3}$ & $\mathrm{CONC}_{5} \mathrm{H}_{4}$ & 55 & 212 & 0.71 & $\mathrm{C}_{22} \mathrm{H}_{15} \mathrm{O}_{3} \mathrm{Cl}_{2} \mathrm{~N}_{3}$ \\
\hline $3 \mathrm{~b}$ & $\mathrm{H}$ & $\mathrm{OCH}_{3}$ & $\mathrm{CSNH}_{2}$ & 50 & 220 & 0.52 & $\mathrm{C}_{16} \mathrm{H}_{11} \mathrm{O}_{2} \mathrm{Cl}_{2} \mathrm{~N}_{3} \mathrm{~S}$ \\
\hline
\end{tabular}

Spectral Interpretation of (3a, 3b)

IR (max cm-1 $\left.{ }^{-1}\right): 3075.1(\mathrm{Ar}-\mathrm{H}) ; 1588,1514(\mathrm{c}=\mathrm{c}) ; 876.6,(\mathrm{C}-\mathrm{H}) ; 635,736 \mathrm{~cm}^{-1}(\mathrm{C}-\mathrm{Cl}) ; 3349(\mathrm{O}-\mathrm{H}) ; 1068,1024$ $(\mathrm{C}-\mathrm{O}) ; 1773(\mathrm{C}=\mathrm{O}) ; 2365.8: 3349(\mathrm{C}-\mathrm{N})$

1HNMR: $\mathrm{OH}\left(\mathrm{CDCl}_{3}\right.$, ppm); 3.92(Si, 3H); 6.3-7.99 ( $\left.\mathrm{m}_{1} 64\right)$

Table 4. Proton - ligand stability constants (pK) of the ligands

\begin{tabular}{|c|c|c|}
\hline System & Ligand $-\mathrm{L}_{1}$ & Ligand $-\mathrm{L}_{2}$ \\
\hline $\mathrm{pK}$ - values & 7.80 & 10.80 \\
\hline
\end{tabular}

$\mathrm{pK}$ ligand $2>\mathrm{pK}$ value 1

It is observed form table 4 , that the proton - ligand stability constant $(\mathrm{pK})$ of ligand - $\mathrm{L}_{1}$ is found to be less. The reduced value of the ligand may be due the presence of dichloro and methoxy $\left(-\mathrm{OCH}_{3}\right)$ electron withdrawing group.

Table 5. Metal ligand stability constants of the complexes

\begin{tabular}{|c|c|c|}
\hline \multirow{2}{*}{ System } & Stability constants & Difference in stability constants \\
\cline { 2 - 3 } & Log $\mathrm{K}_{1}$ & Log $\mathrm{K}_{2}$ \\
\hline $\mathrm{Cu}(\mathrm{II})-\mathrm{L}_{1}$ complex & 8.8250 & 3.1669 \\
\hline $\mathrm{Ni}(\mathrm{II})-\mathrm{L}_{1}$ complex & 8.9250 & 7.7670 \\
\hline $\mathrm{Cu}(\mathrm{II})-\mathrm{L}_{2}$ complex & 7.9447 & 5.3538 \\
\hline $\mathrm{Ni}(\mathrm{II})-\mathrm{L}_{2}$ complex & 6.6447 & 3.2538 \\
\hline
\end{tabular}


It could be seen from table 5 , Ni (II) - $\mathrm{L}_{1}$ Complex occurs simultaneously because there is no as an appreciable difference between $\log K_{1}$ and $\log K_{2}$ values. Rest of complexes occurs step wisely due to sufficient difference between $\log \mathrm{K}_{1}$ and $\log \mathrm{K}_{2}$ values. It is also observed that ligands $\mathrm{L}_{1}$ and $\mathrm{L}_{2}$ both are good chelating agents due to higher stability constant values.

These pyrazoles are identified as good complexing agents and antimicrobial agents.

Ligand Ho. 1 SYSIEU - Mi(I) - Complex
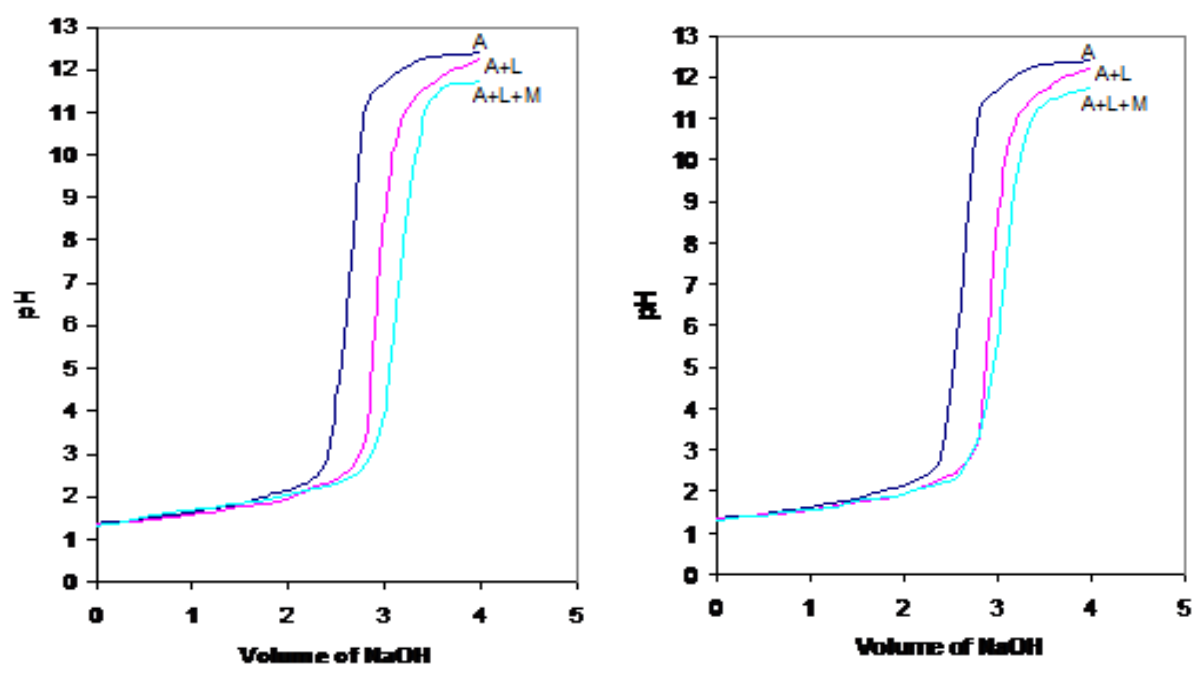

Lo:nd Ho. 2 SYSIE-Culd)-Complex
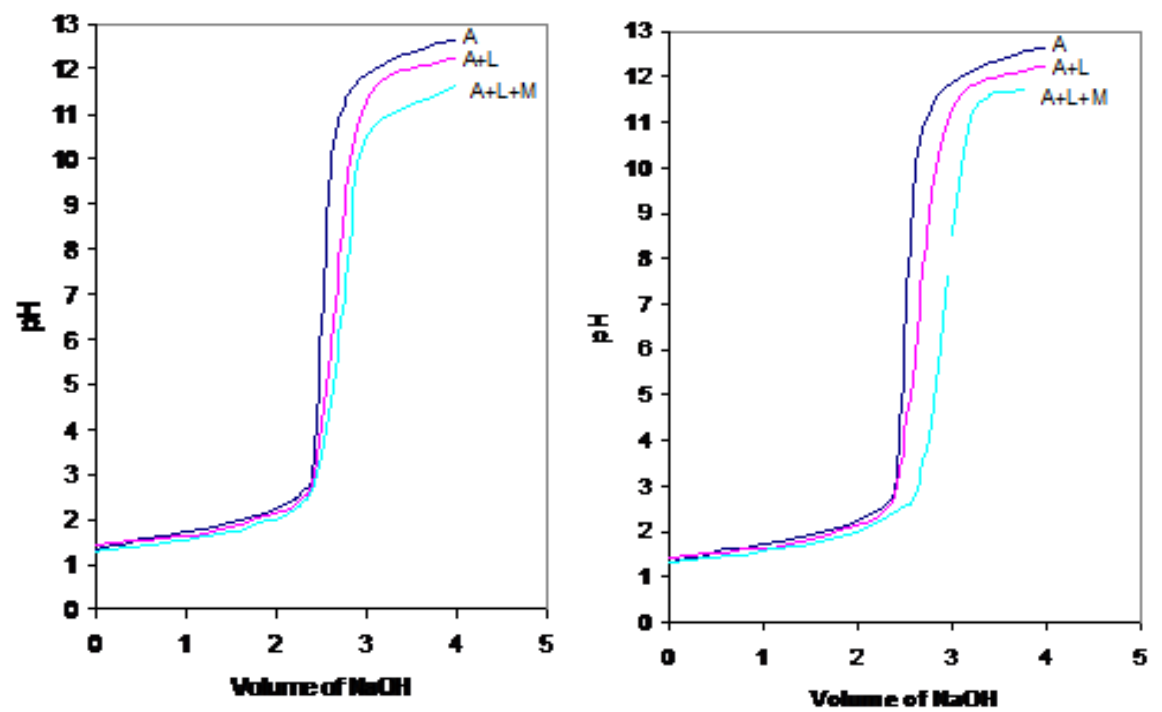

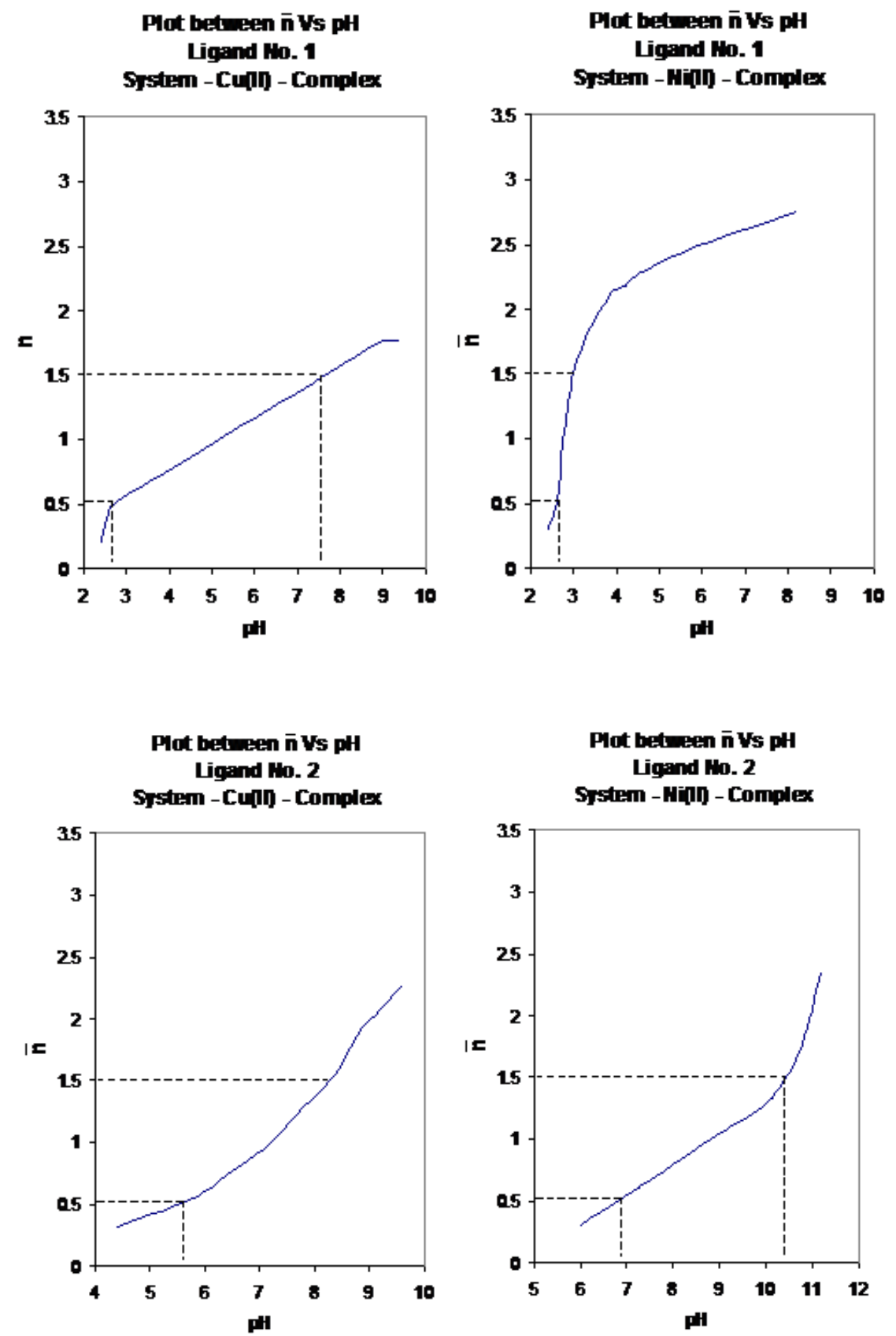